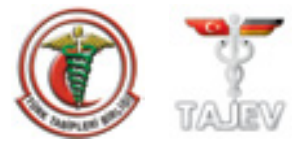

\title{
Impact of obesity on infertility in women
}

\author{
Zeynep Özcan Dağ' ${ }^{1}$ Berna Dilbaz ${ }^{2}$ \\ 'Department of Obstetrics and Gynecology, Kirlkkale University Faculty of Medicine, Kirlkkale, Turkey \\ ${ }^{2}$ Clinic of Reproductive Endocrinology and Infertility, Ankara Etlik Zübeyde Hanım Women's Health Education and \\ Research Hospital, Ankara, Turkey
}

\begin{abstract}
The prevalence of obesity and overweight are increasing and have become an epidemic worldwide. Obesity has detrimental influences on all systems, including reproductive health. The prevalence of obesity in infertile women is high, and it is well known that there is an association between obesity and infertility. The relationship between obesity and reproductive functions is still being explored. Overweight women have a higher incidence of menstrual dysfunction and anovulation. Overweight and obese women are at a high risk for reproductive health. The risk of subfecundity and infertility, conception rates, miscarriage rates, and pregnancy complications are increased in these women. They have poor reproductive outcomes in natural as well as assisted conception. These poor reproductive outcomes include assisted reproduction such as ovulation induction, in vitro fertilization/intracytoplasmic sperm injection (IVF/ICSI), and ovum donation cycles. Weight loss has beneficial effects on the reproductive outcomes in these patients. (J Turk Ger Gynecol Assoc 2015; 16: 111-7)
\end{abstract}

Keywords: Infertility, adipose tissue, obesity

Received: 02 February, 2015

Accepted: 22 April, 2015

\section{Introduction}

Obesity, which is an important health issue, is a common problem among women of reproductive age. Obesity and overweight involves an abnormal and excessive fat accumulation that negatively affects the health of the body. According to the World Health Organization (WHO), if the body mass index (BMI) equals to or is greater than $25 \mathrm{~kg} / \mathrm{m}^{2}$, it is considered overweight, whereas if the BMI equals to or is greater than $30 \mathrm{~kg} / \mathrm{m}^{2}$, it is considered obesity (1).

Obesity brings out many problems such as social, psychological, demographic, and health problems. It is related to increased health risks such as diabetes mellitus, hypertension, coronary heart disease, and osteoarthritis and is linked to various malignancies, particularly endometrium, breast, and colon cancers. Obesity also plays a significant role in reproductive disorders, particularly in women. It is associated with anovulation, menstrual disorders, infertility, difficulties in assisted reproduction, miscarriage, and adverse pregnancy outcomes.

In obese women, gonadotropin secretion is affected because of the increased peripheral aromatization of androgens to estrogens. The insulin resistance and hyperinsulinemia in obese women leads to hyperandrogenemia. The sex hormone-binding globulin (SHBG), growth hormone (GH), and insulin-like growth factor binding proteins (IGFBP) are decreased and leptin levels are increased. Thus, the neuroregulation of the hypothalamic-pituitary-gonadal (HPG) axis deteriorates (2). These alterations may explain impaired ovulatory function and so reproductive health.

Because of lower implantation and pregnancy rates, higher miscarriage rates, and increased maternal and fetal complications during pregnancy, obese women have a lower chance to give birth to a healthy newborn (3-6). In this review, the effects of obesity on fertility and effective management of infertility in obese and overweight women is summarized.

\section{Epidemiology of obesity}

The prevalence of obesity is increasing significantly worldwide. The International Obesity Task Force reported that 1,1 billion adults are overweight. They also reported that 312 million of them are obese (7). Approximately 3,4 million adults die each year because of health problems associated with obesity and being overweight. Of these, $44 \%$ of the problems are related to diabetes, $23 \%$ to ischemic heart disease, and between $7 \%$ and $41 \%$ to some malignancies associated with overweight and obesity (7). The prevelence of obesity has increased in developed countries because of a change in lifestyle, including reduced physical activity, changes in nutrition style, and an increased calorie intake (8). However, some other factors such as endocrine disorders, hormonal disorders, psychological disorders, and use of some drugs such as steroids and antidepressants may lead to obesity (9). The World Health Organization reported that $60 \%$ of women are overweight $\left(\geq 25 \mathrm{~kg} / \mathrm{m}^{2}\right)$ in the United States and most European countries and $30 \%$ of these are obese $\left(\geq 30 \mathrm{~kg} / \mathrm{m}^{2}\right)$ and $6 \%$ of these are morbidly obese $\left(\geq 35 \mathrm{~kg} / \mathrm{m}^{2}\right)(1,7,8)$. 


\section{Obesity and reproductive functions}

The relationship between obesity and reproductive functions has been known for many years $(10,11)$ and it is still being explored (12). The negative effects of obesity on reproductive consequence are well known. However, it is difficult to describe the mechanism of how obesity affects the reproductive system because it is complex and multifactorial. Several mechanisms are involved in the relationship of fertility and obesity. The insulin resistance and leptin levels are increased and hyperandrogenemia occurs in obese women. Similarly, anovulation, changes in adipokine levels and the HPG axis, and steroidogenesis in obese women affects the reproductive system (13-15).

Because of reduced pregnancy rates, increased miscarriage rates, and increased pregnancy complications, live birth rates decrease in obese women in both natural and assisted conceptions. Obesity may impair reproductive functions by affecting both the ovaries and endometrium (15). The HPG axis deteriorates because of changes in hormonal and some substrate levels. The levels of luteinizing hormone (LH), androstenedione, estrone, insulin, triglycerides, and very low density lipoprotein are increased and high density lipoprotein levels are decreased in obese women. Because of these changes, the HPG axis deteriorates and different gynecological effects occur (2).

\section{Adipose tissue and adipokines}

White adipose tissue is a multifunctional organ and it stores energy. It is also an important endocrine organ that regulates energy homeostasis and metabolism by secreting adipokines. These adipokines have important roles in the regulation of a number of physiological processes such as reproduction, immune response, and glucose and lipid metabolism. Adipokines are cytokines predominantly secreted by adipocytes. Some of these adipokines are leptin, adiponectin, resistin, visfatin, omentin, and ghrelin. Adipokines are signaling molecules (hormones), and abnormalities in adipokines can cause inflammation and abnormal cell signaling and thus can lead to deterioration in cell metabolism and function (12). It is well established that an excess or deficiency of white adipose tissue results in sexual maturation disorders, pubertal disorders, and fertility disorders (16). It is well known that stored energy is necessary for the normal function of the reproductive system, including pubertal development, production of reproductive hormones and gametes, and maintenance of pregnancy and lactation. Although adipose tissue is necessary for reproductive function and normal development, the excessive adipose tissue causes some reproductive disturbances.

Excess adipose tissue in women aggravates polycsytic ovarian syndrome (PCOS), and anovulation and may cause hypothalamic hypogonadism (17). In PCOS patients, it has been shown that adipokines such as tumor necrosis factor-alfa (TNF- $\alpha$ ) is increased and some "beneficial adipokines" such as adiponectin is decreased because of dysfunction in the adipose tissue. Abnormal levels of adipokines have been shown to be associated with insulin resistance and type 2 diabetes mellitus (18). The studies demonstrated that as the BMI increases, leptin levels increase both in blood and follicular fluid $(19,20)$. Thus, obesity is associated with high leptin levels in serum and follicular fluid. Leptin has a stimulatory effect on the HPG axis by providing a signal to initiate the reproductive maturation of the hypothalamus. In a mouse model, after increasing the dietary fat intake in both male and female DBA/2J strain mice, insulin resistance and glucose intolerance developed; however, only the female rats had a dietary-induced obesity and hyperleptinemia, thereby causing a $60 \%$ decrease in the spontaneous pregnancy rate (21). Normal ovulatory response and pregnancy rates in these rats after exogenous gonadotropin stimulation indicate a central effect related to increased leptin levels. Leptin inhibits insulin-induced ovarian steroidogenesis by acting on the theca and granulosa cell receptors. Leptin also inhibits LH-stimulated estradiol production by the granulosa cells. The other effect of leptin on reproductive functions is the regulation of early embryo cleavage and development. This may explain the poor reproductive outcomes in obese women (22). Adiponectin is the most common circulating protein synthesized by adipose tissue. In obese women, unlike the other adipose tissue hormones, adiponectin levels decrease $(19,20)$ and increase with weight loss. Adiponectin stimulates glucose uptake in the liver and muscle and decreases hepatic gluconeogenesis. As a result, insulin sensitivity is impaired. Adiponectin also affects lipid synthesis, energy homeostasis, vasodilatation, and atherogenic activity $(23,24)$. Thus, adiponectin decreases triglyceride accumulation and improves insulin sensitivity. In the absence of adiponectin in obese women, plasma insulin levels increase. Consequently, high levels of insulin lead to hyperandrogenemia.

The mechanism of other adipokines on reproductive functions such as resistin and ghrelin has not been fully understood. Resistin is a protein secreted by the adipose tissue. Steppan et al. (25) showed that after a $48 \mathrm{~h}$ fasting period in mice, resistin levels decreased and increased after re-feeding. They studied serum resistin levels in mice that caused obesity and insulin resistance on a high-fat diet. In obese mice, resistin caused insulin resistance and resistin antibody injection increased insulin sensitivity. As a result of increased resistin levels in obesity, insulin resistance occurs and this leads to decreased insulin sensitivity.

Another adipokine, visfatin, is secreted from several cell types and tissues, including adipose tissue and adipocytes, bone marrow, lymphocytes, muscle, liver, trophoblast, and fetal membranes (26). The association between visfatin and obesity and insulin action is not fully understood. It has been reported that visfatin shows insulin-mimetic effects, increases glucose uptake in adipocytes and muscle cells, and decreases glucose release from hepatocytes (26).

Chemerin is another adipokine that affects the adipocyte and glucose metabolism. It has been shown that chemerin levels increase during the metabolic syndrome; therefore, it is associated with obesity, metabolic syndrome, and type 2 diabetes mellitus (27). Chemerin also can impair follicle stimulating hormone (FSH)-induced follicular steroidogenesis and thus can play a role in the pathogenesis of PCOS (28).

Adipose tissue also affects follicular development by the inhibition of gonadotropin secretion through the conversion of andro- 
Table 1. The effects of the adipokines on reproduction

\begin{tabular}{|l|l|l|}
\hline Adipokines & Serum levels in obesity & Effects on reproduction in obesity \\
\hline Leptin & Increases (leptin resistance occurred in obesity) & Inhibits insulin induced ovarian steroidogenesis \\
\hline & & $\begin{array}{l}\text { Inhibits LH*-stimulated estradiol production by the } \\
\text { granulosa cells }\end{array}$ \\
\hline Adiponectin & Decreases & Plasma insulin levels increase \\
\hline Resistin & Increases & Causes insulin resistance \\
\hline Visfatin & Increases & Increased insulin sensitivity \\
\hline Omentin & Decreases & Increased insulin sensitivity \\
\hline Chemerin & Increases & Negatively regulates FSH§-induced follicular steroidogenesis \\
\hline $\begin{array}{l}\text { *luteinizing hormone } \\
\text { \$follicle stimulating hormone } \\
\text { FSH: follicle stimulating hormone; LH: luteinizing hormone }\end{array}$ \\
\hline
\end{tabular}

gens to estrogens in the adipose tissue. Therefore, almost all of the adipokines seem to have their effects on reproduction by causing insulin resistance (Table 1).

\section{Obesity, hyperandrogenemia, and PCOS}

Obesity may not be the only factor that causes hyperandogenemia and anovulation because some obese women are fertile and do not have hyperandrogenism. Hyperinsulinemia and insulin resistance are the underlying causes that lead to obesity, accompanied by hyperandrogenemia, and alterations in steroidogenesis. It has been experimentally shown that insulin has various effects on steroidogenesis. It stimulates ovarian estrogen, androgen, and progesterone production in vitro. Some of these effects occur at physiological concentrations but sometimes may reach higher concentrations. Insulin stimulates androgen production in the theca cells $(29,30)$.

Another mechanism leading to hyperandrogenemia is hyperinsulinemia via insulin-like growth factor-1 (IGF-1). IGF-1 is secreted by human ovarian tissue, and its receptors are located in the ovary. Insulin can bind IGF-1 receptors as well as its own receptor. Insulin also decreases the production of the IGFBP-1 in liver and makes IGF-1 more effective. Androgen production increases from theca interstitial and stromal cells by the action of IGF-1 (31). Insulin decreases SHBG production from the liver; as a result, serum androgen levels increase in obese women (32).

PCOS is also a metabolic disorder characterized by hyperandrogenemia. Formerly, PCOS was known only to be in a hyperandrogenic state, which can lead to infertility. However, current data shows that PCOS is related to an increased risk of metabolic disorders such as insulin resistance (IR), hyperinsulinism (HI), impaired glucose intolerance, and obesity (33). In women with PCOS, weight loss decreases the androgen levels and improves insulin resistance (34).

Hyperinsulinaemia and hyperandrogenaemia changes the ovarian function in both obese and non-obese women. However, the mechanism of how hyperandrogenemia and/or hyperinsulinemia cause anovulation has not been fully understood.

\section{Anovulation and menstrual disturbances}

The mechanism of anovulation in obesity remains unclear. Insulin resistance and hyperandrogenemia significantly increased in obese women, particularly who have central obesity. Hyperandrogenemia due to hyperinsulenemia leads to granulosa cell apoptosis, and this may have an effect on ovarian functions. It is demonstrated that estrogen production in granulosa cells is stimulated by insulin (35).

The effect of FSH on estradiol and progesterone production increases by insulin. This is demonstrated in women with PCOS and insulin resistance. Thus, the estrogen level increases in the developing follicle. FSH enhances the excessive androgen substrate, leading to relatively improper estrogen levels in the developing follicle. Insulin also enhances steroidogenesis by augmenting the effect of LH on granulosa cells. LH stimulates steroidogenesis and inhibits further mitosis and final differentiation of granulosa cells in the preovulatory follicle (36). The effect of LH on granulosa cells is amplified in PCOS patients by the presence of hyperinsulinemia.

As a result of the enhanced steroidogenesis due to insulin and its interaction with LH, the unfavorable milieu causes cessation of the follicle growth. Thus, premature luteinization and follicular arrest develops and leads to menstrual cycle disorders and obesity-induced oligo-anovulation (37).

The increased estrogen due to peripheral convesion disturbs the HPG axis. In conclusion, both the excess estrogen and excess androgens play a role in the anovulation encountered in these patients.

\section{Obesity and miscarriage}

The association between obesity and miscarriage has been reported in a number of studies, both in the general population (38) as well as in women undergoing assisted reproductive techniques (ART) $(39,40)$. A remarkable number of these studies show an increase in the prevalence of miscarriage in case of obesity $(38,41-43)$; however, there are studies that found no association between these two issues $(40,44)$. The link between obesity and miscarriage has been reported in both natural and assisted conceptions. Bellver et al. (43) found a rise in the incidence of spontaneous miscarriage with increasing BMI in patients who had been treated by various ART, including embryo transfer using donor oocytes. The risk of miscarriage was found to be $38.1 \%$ in obese women, whereas this rate was $13.3 \%$ in patients with a normal BMI. In another study, the data 
from 1644 obese women were matched with 3288 controls with normal BMI. Metwally et al. (45) found a higher risk of early, late, and recurrent miscarriage in the obese group.

Although several studies have shown the association between obesity and higher miscarriage rates, there is no consensus about the mechanism that causes this in obese women. It is possible that obesity may affect the embryo or the endometrium or both (45).

One of the proposed mechanisms is the endometrial damage induced by obesity that affects the implantation process more than fertilization and early pregnancy development. In fact, embryo chromosomopathy, the most frequent cause of first trimester miscarriage, does not seem to be increased in women with excess weight (46).

Some endocrine disorders such as PCOS, hypothyroidism, and insulin resistance are more common in overweight women and it is known that the rates of miscarriage are increased in these disorders. Although PCOS is closely associated with obesity, it appears that obesity may also cause miscarriages alone. In a study, Landres et al. (47) found increased euploid miscarriages in obese women regardless of the listed disorders.

In conclusion, alterations in endocrine milieu, embryo quality, or uterine receptivity may contribute to the increased miscarriages (48).

\section{Obesity and infertility}

Infertility is the lack of pregnancy despite regular unprotected sexual intercourse after a year or therapeutic donor insemination in women less than 35 years of age and after 6 months in women 35 years and older (49). It is one of the most frequent disorders of the reproductive system in developing countries. Although many obese multiparous women are able to get pregnant despite their obesity, there is an increased prevalence of infertility in obese women. Vahrati and Smith have found that a larger portion of women who are seeking medical help to get pregnant are obese (50). The studies demonstrated that the duration required to achieve a spontaneous pregnancy rate is increased and pregnancy rates are decreased in obese women, including regular ovulatory obese women $(51,52)$. In several studies, it is found that the risk of infertility is threefold higher in obese women than in non-obese women (53) and their fertility seems to be impaired in both natural and assisted conception cycles $(54,55)$. It has been shown that the probability of pregnancy is reduced by $5 \%$ per unit of BMI exceeding $29 \mathrm{~kg} / \mathrm{m}^{2}(56)$. The association between obesity and lower fertility rate has been shown in several studies, and it has been shown that obesity in early adulthood alters the reproductive functions. The risk of menstrual problems and infertility increased in these women (57). Obesity causes infertility through various pathways, including impaired ovarian follicular development, qualitative and quantitative development of the oocyte, fertilization, embryo development, and implantation (58). The interaction between obesity and fecundity is not fully understood. It seems that the exact cause of infertility is long standing anovulation due to hyperandrogenism.

Grodstein et al. (59) revealed that anovulatory infertility was higher in overweight and obese patients whose BMI was found to be greater than $26.9 \mathrm{~kg} / \mathrm{m}^{2}$. Obesity affects the HPG axis by increased free estrogen levels due to increased conversion of androgens to estrogens in adipose tissue. Increased estrogen causes a decrease in GnRH by negative feedback. Thus, the affected HPG axis causes irregular or anovulatory cycles. Overweight and obese women have a higher incidence of menstrual dysfunction and anovulation. Rogers and Mitchell (10) found that menstrual disturbances were fourfold more common in obese women. Hartz et al. (11) found this incidence to be 3.1 times higher in obese women. Several studies have shown the association between anovulatory infertility and obesity (60-63).

As mentioned above, anovulation is also a result of the effects of hyperinsulinemia, insulin resistance, and hyperandrogenism on steroidogenesis and the ovary. Another situation associated with anovulation and obesity is PCOS. Up to $35 \%-60 \%$ of patients with PCOS are obese, and menstrual disturbances, anovulation, and infertility are more common in these obese PCOS patients than in non-obese PCOS patients (64). Hyperinsulinemia and insulin resistance have been detected in a large number of patients with PCOS with or without of obesity. However, in some studies, a reduced fecundity was reported in overweight and obese women with regular menses (65). These findings suggest that either anovulation continues despite the regular menses, or a combination of possible adverse effects of increased androgens on the endometrium and developing oocytes and adverse effects of increased levels of circulating leptin on the granulosa and theca cells give rise to infertility.

As a conclusion, the negative effect of obesity on infertility, particularly in the presence of anovulation, is clearly shown in several studies.

\section{Obesity and assisted conception}

Because of the obesity epidemic worldwide and its association with infertility, a large number of overweight and obese women are treated using ART. However, poor reproductive outcomes are encountered in ART, such as natural conception, and this is particularly related with central adiposity and PCOS.

Rittenberg et al. (65) found that women who are overweight or obese have a poorer outcome following in vitro fertilization (IVF) treatment than women within normal weight ranges. Metwally et al. (66) demonstrated that there is an association between obesity and poor embryo quality in women below 35 years of age, and young obese women have a less chance of cryopreserved embryos and need a higher dose of gonadotropins. However, Bellver et al. (67) reported an impaired IVF outcome without a poor embryo quality in obese women. They also similarly found that obese women who are undergoing ovarian stimulation in ART programmes require higher doses and a longer period of gonadotropin treatment (65).

Obese infertile women who undergo ART face some difficulties during the treatment. Several studies have shown that the ovarian response to controlled ovarian stimulation in obese women undergoing IVF is low. The other adverse outcomes of ovarian stimulation in obese women are reduced oocyte retrieval, poor quality of oocyte and embryo, decreased intrafollicular human chorionic gonadotrophins concentration, decreased peak estradiol levels, decreased number of mature oocytes, decreased 
incidence of embryo transfer, and decreased number of transferred embryos (68).

The endometrium may also be affected by obesity. Bellver et al. (15) also investigated the potential role of the endometrium for the development of infertility in obesity in ovum donation cycles. Oocytes from healthy, young, non-obese donors are given to recipients with different BMIs. They found that the pregnancy rates per cycle initiated was significantly lower in obese women than in normal weight women (15). Recent meta-analysis have investigated the effects of obesity on the chance of obtaining a pregnancy or a live birth following ART treatment $(65,69,70)$. Rittenberg et al. (65) analyzed 33 reports consisting of 47.967 treatment cycles, and they found that women who were overweight or obese had significantly decreased clinical pregnancy and live birth rates and significantly higher miscarriage rates than women with a normal BMI. Maheshwari et al. (69) analyzed 37 studies, and they found decreased pregnancy and increased miscarriage rates, similar to that by Rittenberg (65), and they found that high doses of gonadotrophins is required in IVF cycles in overweight and obese women. However, why obese women required higher doses of gonadotropin remain unclear. Koning et al. (70) analyzed 27 studies. They found an odds ratio (OR) of 0.90 for the association between overweight and live birth, thus showing a $10 \%$ reduction in the success rates of IVF in overweight women. The effect of obesity on medication requirements has been reported in several studies. Souter et al. (71) found that BMI was negatively associated with the estradiol level produced per preovulatory follicle, resulting in lower estradiol levels with increasing BMI. Some of these studies demonstrated that obesity is related with elevated gonadotropin requirements, lack of follicular development, and reduction in the number of oocytes (72-75). Gonadotropin resistance may be induced by leptin because it is known that the increased concentration of leptin in serum and follicular fluid of obese women decreases estradiol secretion from granulosa cells and may regulate human ovarian steroidogenesis. In high concentrations, leptin acts as an inhibitory gonadotropin (76). The need to increase gonadotropin concentrations is also associated with differences in the absorption, distribution, and clearance rate of the administered gonadotropins by the excessive adipose tissue (71). Akpınar et al. (77) reported an increase in the total gonadotropin consumption and a decrease in the number of retrieved oocytes with an increased body mass index. However, they found an implantation and clinical pregnancy rate in obese and overweight women, similar to normal weight women following intracytoplasmic sperm injection.

In conclusion, recent studies and meta-analyses have shown that the obesity has adverse effects on assisted reproductive technology, including ovulation induction and IVF/ICSI treatments. Obesity reduces the pregnancy rates, live birth rates, and increases the miscarriage rates in treatment cycles.

\section{Obesity and treatment in infertility}

It is difficult to treat anovulatory infertility in obese women because, as mentioned above, the obese women have a lower chance of conception following ART as they require a higher dosage of gonadotropin, respond poorly to ovarian stimulation, and have a higher risk of miscarriage.

Weight loss among overweight and obese women has been shown to improve reproductive outcomes, including fertility. Clark et al. (63) found that even a small weight loss in anovulatory obese infertile women resulted in improvements in ovulation, pregnancy rate, and pregnancy outcome.

Weight loss should be primarily offered to the anovulatory overweight and obese women. However, the effect of weight loss in overweight and obese women with regular menstrual cycles is still unclear. It is important to determine which patients will benefit from weight loss and the interval between the weight loss and the initiation of an ART programme. However, if weight loss will continue for a long time, the patient can enter into a catabolic phase of fertility because advanced age is one of the most deteriorating factors in infertility.

Furthermore, most overweight and obese women have a partner that is also overweight or obese, and overweight men also have been shown to be a risk factor for a prolonged time to achieve pregnancy (78). It is shown in a study that weight loss of these men significantly increased total sperm count and percentage of sperm with normal morphology (79).

\section{Conclusion}

Overweight and obese patients should be informed about the importance of pre-pregnancy weight reduction and should be encouraged to lose weight before the treatment to reduce the poor obstetrical outcomes due to obesity.

Although weight loss is the gold standard of treatment in women with a high BMI, ART treatment should not be delayed too much because of increasing age. Many fertility centers have a protocol to initiate ART treatment; however, there are no evidence-based guidelines regarding fertility treatment in overweight and obese infertile women.

The association between high BMI and adverse fertility outcome is known clearly. There are several proposed mechanisms to explain how obesity may lead to infertility; however, the exact pathophysiology is not clearly understood.

\section{Peer-review: Externally peer-reviewed.}

Author Contributions: Concept - Ö.D.Z., D.B.; Design - Ö.D.Z., D.B.; Supervision - Ö.D.Z., D.B.; Resource - Ö.D.Z.; Materials Ö.D.Z.; Data Collection \& /or Processing - Ö.D.Z., ; Analysis \& /or Interpretation - Ö.D.Z., D.B.; Literature Search - Ö.D.Z.; Writing - Ö.D.Z., D.B.; Critical Reviews - Ö.D.Z., D.B.

Conflict of Interest: No conflict of interest was declared by the authors.

Financial Disclosure: The authors declared that this study has received no financial support.

\section{References}

1. World Health Organization. Preventing and managing the global epidemic. Report of the World Health Organization on obesity. Geneva: World Health Organization, 1997. 
2. Parihar M. Obesity and infertility. Reviews in Gynecological Practice 2003; 3: 120-6. [CrossRef]

3. Fedorcsa'ck P, Storeng R, Dale PO, Tanbo T, Abyholm T. Obesity is associated with early pregnancy loss after IVF or ICSI. Acta Obstet Gynecol Scand 2000; 79: 43-8. [CrossRef]

4. Raatikainen K, Heiskanen N, Heinonen S. Transition from overweight to obesity worsens pregnancy outcome in a BMI dependant manner. Obesity 2006; 14: 165-71. [CrossRef]

5. Callaway LK, Prins JB, Chang AM, McIntyre HD. The prevalence and impact of overweight and obesity in an Australian Obstetric population. Med J Aust 2006; 184: 56-9.

6. Watkins ML, Rasmussen SA, Honein MA, Botto LD, Moore CA. Maternal obesity and risk for birth defects. Pediatrics 2003; 111: 1152-8.

7. Haslam DW, James WP. Obesity. Lancet 2005; 366: 1197-209. [CrossRef]

8. Norman RJ, Noakes M, Wu R, Davies MJ, Moran L, Wang JX. Improving reproductive performance in overweight/obese women with effective weight management. Hum Reprod Update 2004; 10: 267-80. [CrossRef]

9. Pratt LA, Brody DJ. Depression and obesity in the U.S. adult household population, 2005-2010. NCHS Data BrieF 2014; 167: 1-8.

10. Rogers J, Mitchell GW. The relation of obesity to menstrual disturbances. N Engl J Med 1952; 247: 53-6. [CrossRef]

11. Hartz AJ, Barboriak PN, Wong A, Katayama KP, Rimm AA. The association of obesity with infertility and related menstrual abnormalities in women. Int J Obes Rel Metab Dis 1979; 3: 57-77.

12. Jungheim ES, Travieso JL, Carson KR, Moley KH. Obesity and reproductive functions. Obstet Gynecol Clin North Am 2012; 39: 479-93. [CrossRef]

13. Pasquali R, Pelusi C, Genghini S, Cacciari M, Gambineri A. Obesity and reproductive disorders in women. Hum Reprod Update 2003; 4: 359-72. [CrossRef]

14. Linne Y. Effects of obesity on women's reproduction and complications during pregnancy. Obes Rev 2004; 5: 137-43. [CrossRef]

15. Bellver J, Melo MA, Bosch E, Serra V, Remohi J, Pellicer A. Obesity and poor reproductive outcome: the potential role of the endometrium. Fertil Steril 2007; 88: 446-51. [CrossRef]

16. Mircea CN, Lujan ME, Pierson RA. Metabolic fuel and clinical implications for female reproduction. J Obstet Gynaecol Can 2007; 29: 887-902.

17. Tong Q, Xu Y. Central leptin regulation of obesity and fertility. Curr Obes Rep 2012; 1: 236-44. [CrossRef]

18. Kadowaki T, Yamauchi T, Kubota N, Hara K, Ueki K, Tobe K. Adiponectin and adiponectin receptors in insulin resistance, diabetes, and the metabolic syndrome. J Clin Invest 2006; 116: 1784-92. [CrossRef]

19. Metwally M, Li TC, Ledger WL. The impact of obesity on female reproductive function. Obes $\operatorname{Rev} 2007 ; 8$ : 515-23. [CrossRef]

20. Gil-Campos M, Canete RR, Gil A. Adiponectin, the missing link in insulin resistance and obesity. Clin Nutr 2004; 23: 963-74. [CrossRef]

21. Tortoriello DV, McMinn J, Chua SC. Dietary-induced obesity and hypothalamic infertility in female DBA/2J mice. Endocrinology 2004; 145: 1238-47. [CrossRef]

22. Moschos S, Chan JL, Mantzoros CS. Leptin and reproduction: a review. Fertil Steril 2002; 77: 433-44. [CrossRef]

23. Kadowaki T, Yamauchi T. Adiponectin and adiponectin receptors. Endocr Rev 2005; 26: 439-51. [CrossRef]

24. Lee B, Shao J. Adiponectin and energy homeostasis. Rev Endocr Metab Disord 2014; 15: 149-56. [CrossRef]

25. Steppan CM, Bailey ST, Bhat S, Brown EJ, Banerjee RR, Wright CM, et al. The hormone resistin links obesity to diabetes. Nature 2001; 409: 307-12. [CrossRef]
26. Fukuhara A, Matsuda M, Nishizawa M, Segawa K, Tanaka M, Kishimoto K, et al. Visfatin: a protein secreted by visceral fat that mimics the effects of insulin. Science 2005; 307: 426-30. [CrossRef]

27. Bozaoglu K, Bolton K, McMillan J, Zimmet P, Jowett J, Collier G, et al. Chemerin is a novel adipokine associated with obesity and metabolic syndrome. Endocrinology 2007; 148: 4687-94. [CrossRef]

28. Chen X, Jia X, Qiao J, Guan Y, Kang J. Adipokines in reproductive function: a link between obesity and polycystic ovary syndrome. J Mol Endocrin 2013; 50: 21-37. [CrossRef]

29. Poretsky L, Grigorescu F, Seibel M, Moses AC, Flier JS. Distribution and characterization of insulin and insulin-like growth factor 1 receptors in normal human ovary. J Clin Endocrinol Metab 1985; 61: 728-34. [CrossRef]

30. Gilling-Smith C, Willis DS, Beard RW, Franks S. Hypersecretion of androstendione by isolated theca cells from polycystic ovaries. J Clin Endocrinol Metabol 1994; 79: 1158-65. [CrossRef]

31. Giudice LC. Insulin-like growth factors and ovarian follicular development. Endocrine Rev 1992;13: 641-69. [CrossRef]

32. Diamanti-Kandarakis E, Dunaif A. New perspectives in polycystic ovary syndrome. Trends Endocrinol Metab 1996; 7: 267-71. [CrossRef]

33. Cirık DA, Dilbaz B. What do we know about metabolic syndrome in adolescents with PCOS? J Turk Ger Gynecol Assoc 2014; 15: 49-55. [CrossRef]

34. Diamanti-Kandarakis E, Couli C, Tsianateli T, Bergiele A. Therapeutic effects of metformin on insulin resistance and hyperandrogenism in polycystic ovary syndrome. European J Endocrinol 1998; 138: 269-74. [CrossRef]

35. Willis D, Mason H, Gilling Smith C, Franks S. Modulation by insulin of follicle stimulating hormone and luteinizing hormone action in human granulosa cells from normal and polycystic ovaries. J Clin Endocrinol Metab 1998; 81: 302-9. [CrossRef]

36. Hillier SG. Current concepts of the roles of follicle stimulating hormone and luteinizing hormone in folliculogenesis. Hum Reprod 1994; 9: 188-91.

37. Franks S, Robinson S, Willis D. Nutrition, insulin and polycistic ovary syndrome. Rev Reprod 1996; 1: 47-53. [CrossRef]

38. Lashen H, Fear K, Sturdee DW. Obesity is associated with increased risk of first trimester and recurrent miscarriage: matched casecontrol study. Hum Reprod 2004; 19: 1644-6. [CrossRef]

39. Fedorcsak P, Dale PO, Storeng R, Ertzeid G, Bjercke S, Oldereid N, et al. Impact of overweight and underweight on assisted reproduction treatment. Hum Reprod 2004; 19: 2523-8. [CrossRef]

40. Lashen H, Ledger W, Bernal AL, Barlow D. Extremes of body mass do not adversely affect the outcome of superovulation and in-vitro fertilization. Hum Reprod 1999; 14: 712-5. [CrossRef]

41. Hamilton-Fairley D, Kiddy D, Watson H, Paterson C, Franks S. Association of moderate obesity with a poor pregnancy outcome in women with polycystic ovary syndrome treated with low dose gonadotrophin. Br J Obstet Gynaecol 1992; 99: 128-31. [CrossRef]

42. Bussen S, Sutterlin M, Steck T. Endocrine abnormalities during the follicular phase in women with recurrent spontaneous abortion. Hum Reprod 1999; 14: 18-20. [CrossRef]

43. Bellver J, Rossal LP, Bosch E, Zuniga A, Corona JT, Melendez F, et al. Obesity and the risk of spontaneous abortion after oocyte donation. Fertil Steril 2003; 79: 1136-40. [CrossRef]

44. Loveland JB, McClamrock HD, Malinow AM, Sharara FI. Increased body mass index has a deleterious effect on in vitro fertilization outcome. J Assist Reprod Genet 2001; 18: 382-6. [CrossRef]

45. Metwally M, Tuckerman EM, Laird SM, Ledger WL, Li TC. Impact of high body mass index on endometrial morphology and function in the peri-implantation period in women with recurrent miscarriage. Reprod Biomed Online 2007; 14: 328-34. [CrossRef] 
46. Bellver J, Cruz F, MartínezMC, Ferro J, Ramírez JF, Pellicer A, Garrido N. Female overweight is not associated with a higher embryo euploidy rate in first trimester miscarriages karyotyped by hysteroembryoscopy. Fertil Steril 2011; 96: 931-3. [CrossRef]

47. Landres IV, Milki AA, Lathi BR. Karyotype of miscarriages in relation to maternal weight Hum Reprod 2010; 25: 1123-26. [CrossRef]

48. Luke B, Brown MB, Stern JE, Missmer SA, Fujimoto VY, Leach R, SART Writing Group. Female obesity adversely affects assisted reproductive technology (ART) pregnancy and live birth rates. Hum Reprod 2011; 26: 245-52. [CrossRef]

49. Practice Committee of American Society for Reproductive Medicine. Definitions of infertility and recurrent pregnancy loss: a committee opinion. Fertili Steril 2013; 99: 63. [CrossRef]

50. Vahratian A, Smith YR. Should access to fertility-related services be conditional on body mass index? Hum Reprod 2009; 24: 1532-37. [CrossRef]

51. Gesink Law DC, Maclehose RF, Longnecker MP. Obesity and time to pregnancy. Hum Reprod 2007; 22: 414-20. [CrossRef]

52. Wise LA, Rothman KJ, Mikkelsen EM, Sørensen HT, Riis A, Hatch EE. An internet-based prospective study of body size and time-topregnancy. Hum Reprod 2010; 25: 253-64. [CrossRef]

53. Rich-Edwards JW, Goldman MB, Willet WC, Hunter DJ, Stamfer MJ, Colditz GA, et al. Adolescent body mass index and infertility caused by ovulation disorders. Am J Obstet Gynecol 1994; 171: 171-7. [CrossRef]

54. Zaadstra BM, Seidell JC, Van Noord PA, te Velde ER, Habbema JA, Vrieswijk B, Karbaat J. Fat and female fecundity: Prospective study of effect of body fat distribution on conception rates. BMJ 1993; 306: 484-7. [CrossRef]

55. Crosignani PG, Ragni G, Parazzini F, Wyssling H, Lombrosso G, Perotti L. Anthropometric indicators and response to gonadotrophin for ovulation induction. Hum Reprod 1994; 9: 420-3.

56. Van der Steeg JW, Steures P, Eijkemans MJ, Habbema JD, Hompes PG, Burggraaff JM, et al. Obesity affects spontaneous pregnancy chances in subfertile ovulatory women. Hum Reprod 2008; 23: 324-8. [CrossRef]

57. Lake JK, Power C, Cole TJ. Women's reproductive health: the role of body mass index in early and adult life. Int J Obes Relat Metab Disord 1997; 21: 432-38. [CrossRef]

58. Jungheim ES, Travieso JL, Hopeman MM. Weighing the impact of obesity on female reproductive function and fertility. Nutr Rev 2013; 71: 3-8. [CrossRef]

59. Grodstein F, Goldman MB, Cramer DW. Body mass index and ovulatory infertility. Epidemiology 1994;5: 247-50. [CrossRef]

60. Green BB, Weiss NS, Daling JR. Risk of ovulatory infertility in relation to body weight. Fertil Steril 1988; 50: 721-26.

61. Jensen TK, Scheike T, Keiding N, Schaumburg I, Grandjean P. Fecundability in relation to body mass and menstrual cycle patterns. Epidemiology 1999; 10: 422-8. [CrossRef]

62. Bolumar F, Olsen J, Rebagliato M, Saez-Lloret I, Bisanti L. Body mass index and delayed conception: a European Multicenter Study on Infertility and Subfecundity. Am J Epidemiol 2000; 151: 1072-9. [CrossRef]

63. Clark AM, Thornley B, Tomlinson L, Galletley C, Norman RJ. Weight loss in obese infertile women results in improvement in reproductive outcome for all forms of fertility treatment. Hum Reprod 1998; 13: 1502-5. [CrossRef]
64. Al-Azemi M, Omu FE, Omu AE. The effect of obesity on the outcome of infertility management in women with polycystic ovary syndrome. Arch Gynecol Obstet 2004; 270: 205-10. [CrossRef]

65. Rittenberg V, Seshadri S, Sunkara SK, Sobaleva S, Oteng-Ntim E, El-Toukhy T. Effect of body mass index on IVF treatment outcome: an updated systematic review and meta-analysis. Reprod Biomed Online 2011; 23: 421-39. [CrossRef]

66. Metwally M, Cutting R, Tipton A, Skull J, Ledger WL, Li TC. Effect of increased body mass index on oocyte and embryo quality in IVF patients. Reprod Biomed Online 2007; 15: 532-8. [CrossRef]

67. Bellver J, Ayllón Y, Ferrando M, Melo M, Goyri E, Pellicer A, et al. Female obesity impairs in vitro fertilization outcome without affecting embryo quality. Fertil Steril 2010; 93: 447-54. [CrossRef]

68. Norman RJ, Moran LJ. Weight, fertility and management approaches. In: Kruger TF, Van der Spuy Z, Kempers RD, editors. Advances in fertility studies and reproductive medicine. Capetown: Juta; 2007. p. 24-35.

69. Maheshwari A, Stofberg L, Bhattacharya S. Effect of overweight and obesity on assisted reproductive technology - a systematic review. Hum Reprod Update 2007; 13: 433-44. [CrossRef]

70. Koning AM, Mutsaerts MA, Kuchenbecker WK, Broekmans FJ, Land JA, Mol BW, Hoek A. Complications and outcome of assisted reproduction technologies in overweight and obese women. Hum Reprod 2012; 27: 457-67. [CrossRef]

71. Souter I, Baltagi LM, Kuleta D, Meeker JD, Petrozza JC. Women, weight, and fertility: The effect of body mass index on the outcome of superovulation/intrauterine insemination cycles. Fertil Steril 2011; 95: 1042-47. [CrossRef]

72. Fedorcsak P, Dale PO, Storeng R, Tanbo T, Abyholm T. The impact of obesity and insulin resistance on the outcome of IVF or ICSI in women with polycystic ovarian syndrome. Hum Reprod 2001; 16: 1086-91. [CrossRef]

73. Loh S, Wang JX, Matthews CD. The influence of body mass index, basal FSH and age on the response to gonadotrophin stimulation in nonpolycystic ovarian syndrome patients. Hum Reprod 2002; 17: 1207-11. [CrossRef]

74. Mulders AG, Laven JS, Eijkemans MJ, Hughes EG, Fauser BC. Patient predictors for outcome of gonadotropin ovulation induction in women with normogonadotrophic anovulatory infertility: a meta-analysis. Hum Reprod Update 2004; 9: 429-49. [CrossRef]

75. Spandorfer SD, Kump L, Goldschlag D, Brodkin T, Davis OK, Rosenwaks Z. Obesity and in vitro fertilization: negative influences on outcome. J Reprod Med 2004; 49: 973-7.

76. Agarwal SK, Vogel K, Weitsman SR, Magoffin DA. Leptin antagonizes the insulin-like growth factor-I augmentation of steroidogenesis in granulosa and theca cells of the human ovary. J Clin Endocrinol Metab 1999; 84: 1072-6. [CrossRef]

77. Akpınar F, Demir B, Dilbaz S, Kaplanoğlu I, Dilbaz B. Obesity is not associated with the poor pregnancy outcome following intracytoplasmic sperm injection in women with polycystic ovary syndrome. J Turk Ger Gynecol Assoc 2014; 15: 144-8. [CrossRef]

78. Ramlau-Hansen CH, Thulstrup AM, Nohr EA, Bonde JP, Sørensen TI, Olsen J. Subfecundity in overweight and obese couples. Hum Reprod 2007; 22: 1634-7. [CrossRef]

79. Håkonsen LB, Thulstrup AM, Aggerholm AS, Olsen J, Bonde JP, Andersen CY, et al. Does weight loss improve semen quality and reproductive hormones? Results from a cohort of severely obese men. Reprod Health 2011; 8: 24. [CrossRef] 